[ C H A P T E R O NE ]

\title{
HOBBES'S PRESCRIPTIVE ARGUMENTS
}

In 1705 , Samuel Clarke undertook a demonstration of the fitness of morality. Clarke thought his task so easy- "These things," he declared, "are so notoriously plain and self-evident, that nothing but the extremest stupidity of Mind, corruption of Manners, or perverseness of Spirit, can possibly make any Man entertain the least doubt concerning them"-that his readers may well have wondered why he found it necessary to argue the point. Anticipating just this rejoinder, Clarke noted, "Indeed it might justly seem altogether a needless undertaking, to attempt to prove and establish the eternal difference of Good and Evil; had there not appeared certain Men, as Mr Hobbes and some few others, who have presumed, contrary to the plainest and most obvious reason of mankind, to assert, and not without some

Throughout the chapter, I cite from Thomas Hobbes, Leviathan, ed. C. B. Macpherson (Harmondsworth: Penguin, I 968); the Anchor De Homine and Pbilosophical Rudiments Concerning Government (Man and Citizen, ed. Bernard Gert [New York: Doubleday, I972]); Tönnies's Elements (The Elements of Law Natural and Politic, ed. Ferdinand Tönnies, 2d ed. [New York: Barnes \& Noble, I 969]); and Joseph Cropsey's Dialogue (A Dialogue between a Philosopher and a Student of the Common Laws of England, ed. Joseph Cropsey [Chicago: University of Chicago Press, I97 I]). For all the rest of Hobbes's works, and additionally for these (except for De Homine, tranlated from Hobbes's Latin), I cite from The English Works of Thomas Hobbes, ed. William Molesworth, i I vols. (London, I 839- I 845), as EW. Finally, italics throughout are Hobbes's own, unless otherwise noted. 
Subtilty indeavoured to prove, that there is no such real Difference originally, necessarily, and absolutely in the Nature of Things." Clarke then went on at some length to argue against one "notorious Absurdity and Inconsistency in Mr Hobbes' Scheme" after another.'

Hobbes incurred Clarke's wrath (and, for that matter, that of Ralph Cudworth, Henry More, and countless others ${ }^{2}$ ) by denying the objectivity of values: "Whatsoever is the object of any mans Appetite or Desire; that is it, which he for his part calleth Good: and the object of his Hate, and Aversion, Evill; And of his Contempt, Vile and Inconsiderable. For these words of Good, Evill, and Contemptible, are ever used with relation to the person that useth them: There being nothing simply and absolutely so; nor any common Rule of Good and Evill, to be taken from the nature of the objects themselves." ${ }^{3}$ Nor has the vitriol launched at Hobbes been exclusively of seventeenth- and eighteenth-century vintage. In this century, one scholar labeled Hobbes a "moral defective"; another, after quoting some of Hobbes's skeptical statements, commented, "It is idle to qualify or defend such a political philosophy: it is rotten at the core."

Hobbes may be a dauntless skeptic, but he hardly abstains from the suspect vocabulary of evaluation. Talk of just and unjust, right and wrong, duty and obligation, natural right and nat-

'Samuel Clarke, Discourse upon Natural Religion, excerpted in British Moralists, ed. L. A. Selby-Bigge, 2 vols. (Oxford, , 897), II:6, 40; also in D. D. Raphael's edition of the Moralists, 2 vols. (Oxford: Clarendon, I969), I: 194, 2 I 9.

'Samuel Mintz's The Hunting of Leviathan (Cambridge: Cambridge University Press, 1962), a fascinating study of contemporary reactions to Hobbes, contains virtually no discussion of the reaction to Hobbes's skepticism (see pp. 153-154).

${ }^{3}$ Leviatban, p. 120 (EW III:41). Hobbes here denies that values are objective and affirms that evaluative discourse is emotive. The two theses are independent. See too the skeptical claims in his early tract on first principles in Elements, p. 208; also Elements, pp. 29, 93-94 (EW IV:32, 109); Rudiments, pp. 1 50, 282-283 (EW II:47, 196); Leviatban, pp. I 20, 216 (EW III:4 I, 146); De Homine, p. 47; EW V:192; EW VI:220.

"George Catlin, Thomas Hobbes as Philosopher, Publicist, and Man of Letters (Oxford: Basil Blackwell, 1922), p. 14; W. G. Pogson Smith, in a posthumous essay prefacing the Oxford edition of Hobbes's Leviatban (Oxford: Clarendon, 1967), p. xvii. I owe the Catlin reference to Mintz, p. 155. 
ural law, good and bad, merit and due, flows freely from his pen. He carefully distinguishes between just men and just actions, ${ }^{5}$ insists that "the laws of nature are immutable and eternal," and discourses at length on the duties and obligations of sovereigns.' His moral claims may often strike us as idiosyncratic, made of the same stuff as the careening world of The Mikado, where "I am right, and you are right, and all is right as right can be!" Nonetheless, they do seem genuinely moral, so much so that a sizable literature is devoted to vindicating Hobbes from charges of outrageous skepticism and moral defectiveness. ${ }^{8}$ Yet on Hobbes's own account, we seem bound to take his putatively moral talk as a curiously disguised version of his personal preferences, to take Leviathan in turn as the confessions of his particular aversions and desires.

So Hobbes appears badly inconsistent on the fundaments of ethics. He often makes out apparently moral arguments, yet he also casts the whole business of moral argument in a radically skeptical light. This puzzle, I think, has given rise to the obligation controversy in the literature on Hobbes. I intend to offer a reading of Hobbes that will resolve at least some of that controversy. Yet my interest is not purely explicative: I want to assess

${ }^{5}$ Elements, pp. 83-84 (EW IV:97-98); Rudiments, pp. I38-139 (EW II:32-33); Leviathan, pp. 206-208 (EW III: I 35- I 37); De Homine, pp. 74-75.

${ }^{6}$ Rudiments, p. I40 (EW II:46); the same without the italics in Leviathan, p. 2 I 5 (EW III: I 45); the lawyer and the philosopher, Dialogue, pp. 55-56, I40 $(E W$ VI:6, I 22), agree here.

'Elements, pp. 178-I84 (EW IV:2 I3-220); Rudiments, pp. 257-270 (EW II:I65-I8I); Leviatban, pp. 376-394 (EW III:322-343); see too $E W$ $\mathrm{V}: 177-178$.

${ }^{8}$ A. E. Taylor, "The Ethical Doctrine of Hobbes," Pbilosopby i 3 (October 1938): 406-424, reprinted in K. C. Brown, ed., Hobbes Studies (Oxford: Basil Blackwell, 1965); Howard Warrender, The Political Pbilosopby of Hobbes (Oxford: Clarendon, I957); Harvey C. Mansfield, Jr., "Hobbes and the Science of Indirect Government," American Political Science Review 65 (March 1971): 97I Io; Gert's introduction to Man and Citizen; David Gauthier, "Thomas Hobbes: Moral Theorist," Journal of Pbilosophy 76 (October 1979): 547-559. The position here is different from that of Gauthier's earlier The Logic of Leviathan (Oxford: Clarendon, I969). I suspect that Michael Oakeshott, Hobbes on Civil Association (Berkeley: University of California Press, 1975), intends a moral reading. C. B. Macpherson, The Political Theory of Possessive Individualism (Oxford: Clarendon, 1962), pp. 7I-78, argues that Hobbes successfully bridges the is/ought gap. 
Hobbes's prescriptive arguments, and I want to provoke doubts about moral arguments and the state. I am concerned only indirectly with the content of Hobbes's prescriptive arguments. My real concern is with their structure. I will not, for example, argue at any length for any account of what Hobbes believes we are obliged to do; I will argue at some length for an account of Hobbes's theory of how one goes about demonstrating an obligation.

I begin with a presentation of Hobbes's prudential argument, along with a rebuttal to the claim that that is all Hobbes has to offer. I move on to puzzle over an argument Hobbes uses again and again, one I call the argument from necessity. More confidently, I present Hobbes's views on science and truth and argue that they provide Hobbes with what I call an argument from ordinary language for morality. That argument seems empty, so finally I examine Hobbes's faltering attempts to inject some substance into his moral argument.

\section{The Prudential Argument}

Hobbes is best known for his prudential argument, ideally showing that obedience to an absolute sovereign is in everyone's interest. Whether that argument is all Hobbes employs I set aside for the moment; first I want to sketch the argument itself.

Hobbes invites us to "consider men as if but even now sprung out of the earth, and suddenly, like mushrooms, come to full maturity, without all kind of engagement to each other"9-men, most notably, not under any authority. Hobbes argues first that those so situated would be equal in decisive respects: "as to the strength of body, the weakest has strength enough to kill the strongest"; as to mental ability, "they will hardly believe there be many so wise as themselves," and, he adds ironically, "this proveth rather that men are in that point equall, than unequall. For there is not ordinarily a greater signe of the equall distribu-

${ }^{9}$ Rudiments, p. 205 (EW II: 109). 
tion of any thing, than that every man is contented with his share."10

The next premise of the argument is that "every man is desirous of what is good to him, and shuns what is evil . . . by a certain impulsion of nature, no less than that whereby a stone moves downward." So arises the vexing question of whether, or in what sense, Hobbes was a psychological egoist, a question in which I do not wish to become embroiled. ${ }^{12}$ Hobbes does not consistently maintain that all voluntary actions arise from the actor's concern with his or her own welfare; he tells us, for example, that people will violate the social contract and so risk punishment when "either themselves or their near friends are to suffer." 13 Nor is his egoism merely "tautological," "based upon the statement stipulating the use for 'good." "14 Hobbes's claim that "no man can be ignorant that the voluntary actions of men, by a natural necessity, do follow those opinions which they have concerning good and evil, reward and punishment"1s is apparently not a claim about the use of the words good, evil, reward, and punishment. Hobbes thinks that whenever we believe something to be good (or the best), we pursue it. He does not allow for

${ }^{10}$ Leviatban, p. 184 ( $E W$ III: I I I). The separate attention to mental equality is new in Leviatban; in Elements, p. 70 (EW IV:8 I-82), and Rudiments, p. I I4 (EW II:6-7), Hobbes contents himself with the grim equality of the ability to kill.

"Rudiments, p. 205 (EW II: I09).

${ }^{12}$ Hobbes seems to maintain psychological egoism in Elements, pp. 71, 73, 74, 84, 99- 100 (EW IV:83, 85, 86, 98-99, I 1 7); Rudiments, pp. I 18 , I 25, I 3 I , I46, 1 76, 2 I 2, 283, 365 (EW II: 1 2, 19, 26, 42, 75, 1 16, 196, 293); Leviathan, pp. 192, 209, 2 I 3, 244, 303, 310-3II, 339, 567 (EW III:I 20, I 38, I 43, 176- I 77, 24I, 250, 28I , 537); De Homine, p. 48; $E W$ V I:200. Especially compelling is the psychology in Elements, pp. $31-48$ (EW IV:34-53), partly reprinted in Raphael's Moralists, I:6- 15, whose egoistic content is purged in Leviathan; note here F. S. McNeilly, The Anatomy of Leviatban (London: Macmillan, 1968), pp. 96- I 36, especially I06-I 17 .

${ }^{13}$ Rudiments, pp. 176- I77 (EW II:75). It could be claimed that one may feel personally threatened when one's close friends are attacked, but see too Rudiments, p. I83 (EW II:83); Leviatban, p. I 80 (EW III: 106-107); and De Homine, p. 60.

${ }^{14}$ Stuart M. Brown, Jr., "Hobbes: The Taylor Thesis," Pbilosopbical Review 68 (July 1959): 322, reprinted in Brown, Hobbes Studies, p. 70 . See too Gert's introduction to Man and Citizen, pp. 5- I3.

${ }^{15 R u d i m e n t s, ~ p . ~} 365$ (EW II:293). 
variants of weakness of will or neurosis. People often do act against their own true good; they are misled by passion, or reason badly, or don't have the requisite information. But they do proceed, on Hobbes's account, always and necessarily to pursue what they think is good. This, I take it, is the meaning of Hobbes's dictum "To will an error, is impossible,"16 as well as the upshot of his account of the will.

But back to our freshly ripened mushroom-men, who already are coming to blows. Since "many men's appetites carry them to one and the same end; which end sometimes can neither be enjoyed in common nor divided, it followeth that the stronger must enjoy it alone, and that it be decided by battle who is the stronger." 17 Put this way, the argument is too abrupt. Why can't they amicably agree that the stronger should prevail, or hit upon a fair solution?

Hobbes, however, offers a more subtle and compelling argument to the same end. He claims that human desire is necessarily insatiable, a claim he def tly derives from his materialism: "There is no such thing as perpetuall Tranquillity of mind, while we live here; because life it selfe is but Motion, and can never be without Desire, nor without Feare, no more than without Sense." ${ }^{18}$ We can leave aside the quaintly scientistic trappings of Hobbes's physiological psychology. His belief that "ambition and greediness of honours cannot be rooted out of the minds of men"19 leads to a more compelling line of argument. Honor is one of those curious positional goods, and scarcity is built into the logic of its social distribution: "Glory is like honour; if all men have it no man hath it, for they consist in comparison and precellence." $" 20$

Hobbes believes too that it is distinctively human to plan for the future. He tells us that "man is famished even by future hun-

${ }^{16}$ Rudiments, p. 358 (EW II:285); also Dialogue, p. 126 (EW VI: I 02).

${ }^{17}$ Elements, p. 71 ( $E W$ IV:82).

${ }^{18}$ Leviatban, Pp. I 29-I 30 (EW III:5I); also pp. I39, I60-I6I (EW III:62, 85).

${ }^{19}$ Rudiments, p. 265 (EW II:175); see too Elements, p. 102 (EW IV:1 20); Rudiments, pp. 168, 229, 252, 265 (EW II:66-67, 1 36, 160, 175); Leviathan, p. 225 (EW III:1 56).

${ }^{20}$ Rudiments, p. 113 (EW II:5). 
ger." the Desires, as Scouts, and Spies, to range abroad, and find the way to the things Desired." ${ }^{22}$ Looking ahead, Hobbes's hypothetical men find that some will seek to satisfy all their desires. ${ }^{23}$ The recklessness of these impetuous, vainglorious fellows precipitates a state of general insecurity. Even those who would be willing somehow to contain their own desires are forced to compete for scarce resources. So arises "a general inclination of all mankind, a perpetuall and restlesse desire of Power after power, that ceaseth only in Death." ${ }^{24}$

Briefly, the argument so far is that "masterlesse men"2s are forced, whether they like it or not, into a mad scramble for scarce resources. In looking ahead, each sees that some men will always seek more, so each "cannot assure the power and means to live well, which he hath present, without the acquisition of more." ${ }^{26}$ As far as the logic of the argument goes, all Hobbes needs to say is that it would be prudent to infer that someone might seek more. We might then look askance at his venturing the further claim that indeed some will seek more. That claim hardly seemed problematic, though, in a society all too familiar with a grasping nobility. In any case, the race is on, and its bleak outcome is recorded in Hobbes's celebrated litany of woes:

In such condition, there is no place for Industry; because the fruit thereof is uncertain: and consequently no Culture of the Earth; no Navigation, nor use of the commodities that may be imported by Sea; no commodious Building; no Instruments of moving, and removing such things as require much force; no knowledge of the face of the Earth; no account of Time; no Arts; no Letters; no Society; and which is worst of all, continuall fear, and danger of vio-

${ }^{21}$ De Homine, p. 40.

${ }^{22}$ Leviatban, p. 139 (EW III:6I); also Rudiments, p. 282 (EW II: I 95). Note too reason's devotion to low time preference in De Homine, p. 55.

${ }^{23}$ Elements, p. 7 I (EW IV:82); Rudiments, p. 114 (EW II:7); Leviathan, pp. I 6 I , I 84- I 85 (EW III: 85-86, I I I-I I 2).

${ }^{24}$ Leviathan, p. 161 (EW III:85-86).

${ }^{25}$ Leviatban, Pp. 238,266 (EW III: 1 70, 20I).

${ }^{26}$ Leviatban, p. I6I (EW III:86). Hobbes offers a somewhat different summary of the argument in Leviatban, p. 185 ( $E W$ III: I I 2). 
lent death; And the life of man, solitary, poore, nasty, brutish, and short. ${ }^{27}$

No one likes "this warre of every man against every man," for, Hobbes tells us, "all men agree on this, that Peace is Good." Hobbes offers two arguments to show why peace is good. He claims that we naturally "avoid that which is hurtful; but most of all that terrible enemy of nature, death, from whom we expect both the loss of all power, and also the greatest of bodily pains in the losing." ${ }^{30}$ But fear of violent death is readily overemphasized. Hobbes has latched onto a far more powerful sociological argument, leaving the contentious realm of human nature aside. The key here is again the logic of insecurity. Trust is an essential ingredient in cooperation; without it, all sorts of enterprises founder. And there can be no trust without peace. Peace is not the end of human life: "There is no such Finis ultimus, (utmost ayme,) nor Summum Bonum, (greatest Good,) as is spoken of in the Books of the old Morall Philosophers." ${ }_{11}$ Rather, peace is an essential requirement for realizing one's ends. Hobbes tends to portray what looks to jaundiced critics like a scandalously sedate bourgeois life, or living "delightfully," as the likely end. Yet the argument holds good for all kinds of life plans-including, for example, the pursuit of virtue. There is simply no reason to take Hobbes's emphasis on peace as the betrayal of a traditional concern with the good life.

The state of nature poses an unmistakably severe problem and so calls forth Hobbes's draconian solution: the erection of an ab-

${ }^{27}$ Leviatban, p. 186 (EW III: I I 3$)$.

${ }^{28}$ Leviatban, p. 188 (EW III: I I 5); also Rudiments, p. I I 8 (EW II: I 2$)$.

${ }^{29}$ Leviathan, p. 2 I 6 (EW III: 146).

${ }^{30}$ Elements, p. 7 I $(E W$ IV:83).

${ }^{31}$ Leviatban, p. I 60 (EW III:85).

${ }^{32}$ Hobbes's usual language is "commodious"; for delight and delectation, see Rudiments, p. 259 (EW II:I67-I68). Gert, in his introduction to Man and Citi$z e n$, p. 15 , detects a categorical imperative in "reason declaring peace to be good" and similar constructions. See Rudiments, p. I 5 I (EW II:48) and p. 150 (EW II:47); Elements, p. 74 (EW IV:86). But a more modest gloss will do the trick: reason declares peace to be good, meaning simply that reason discovers that peace is necessary for satisfying desire. 
solute sovereign. The lack of authority, remember, is one of the factors that get the mushroom-men into such a scrape. Under authority, the vainglorious will be deterred, by threat of punishment, from their inflammatory pursuit of power. When men look ahead, then, they will discover no incipient mischief. Just as peace is required for the goods offered by social cooperation, so, Hobbes suggests, the sovereign is required for peace. Once these men see the availability of a solution, they will "by a natural necessity" flock to it, provided each has some assurance the others are doing the same. So Hobbes solves the problem he poses his masterless men.

Why should we take any interest in such overtly hypothetical tales? Why should we take some hypothetical men's hypothetical willingness to establish and obey an absolute sovereign as indicating anything whatever about our doing so? Hobbes's answer would be that, should we choose to disobey our sovereign, we will find ourselves in the entirely unenviable position of those hypothetical creatures, anxiously praying for an absolute sovereign; so we might as well learn a lesson from them and obey our sovereign in all things (except when the sovereign threatens our life or salvation or has lost effective power). Both by introspection and by our experience of jealously locked doors, we can know that we are like them. ${ }^{33}$ Here, then, is the prudential argument. Whatever our ends, we need peace to achieve them; peace can be enjoyed securely only under an absolute sovereign; so in a strictly prudential sense we ought to obey an absolute sovereign.

The argument is addressed to us, not to hypothetical men; it is designed to show us why we should obey our real sovereign, not to show them why they should have a hypothetical one. Two points follow. First, the accusation that Hobbes illicitly smuggles psychological and social facts about bourgeois men into his state of nature ${ }^{34}$ is misplaced. If he is addressing bourgeois men,

${ }^{33}$ Elements, p. I (EW IV:I-2); Rudiments, pp. 99, I03 (EW II:xv, xx); Leviathan, pp. 83, I 86- I 87 (EW III:xii, I $13-1$ I 4 ); EW I:74.

${ }^{34}$ At least intimated by Macpherson, Political Theory of Possessive Individualism, pp. 17-29, and surely urged by Rousseau in the second Discourse. 
those facts belong in the state of nature, ${ }^{35}$ for it is those bourgeois men who will find themselves in that state of nature if they overthrow their sovereign. We ought not to be misled by the word nature into thinking that Hobbes is painting some pristine portrait of human nature stripped of all the effects of social context. His state of nature is a curious melange of asocial anarchy, with neither arts nor letters, and psychological traits as quintessentially social as honor and vainglory. Hobbes flirts with no incoherence in blending the two: some of society would collapse without politics, he thinks, but not all. ${ }^{36}$ Second, as far as the prudential argument goes, the social contract weakens Hobbes's position. Hard pressed as he is to tell a convincing story about how the gladiators of the war of all against all might manage to convoke a meeting and agree on a sovereign, Hobbes would perhaps do better to deny the very possibility of any escape from his state of nature. Though historically extravagant, such a denial would render even more horrible the consequences of disobeying and so toppling a sovereign: the life of man would then be solitary, poor, nasty, brutish, and short - forever.

Barring the accidents of chronology, the argument could have been formulated in terms of game theory as a large-scale prisoners' dilemma. The highest payoff to each player would attach to convergence on agreement to an absolute sovereign; but each player would know that if he renounces some powers and (enough) others don't, an awfully harsh payoff awaits. Limited knowledge, preplay communication, and commitment possibilities would be built into the game: each player would not be sure if others were willing to squelch their infinite desires in the interests of peace; each would be unable to communicate readily with

${ }^{35}$ Hobbes sometimes suggests that Leviathan was intended simply to calm down his frenzied contemporary England: $E W$ VII:5, 335-336. Were that so, he could legitimately import into his state of nature any and all extrapolitical facts about England around 1650 .

${ }^{36}$ But why does Hobbes call it the natural state of man, and what does he mean by suggesting that politics is conventional? He wishes to invert and so mock a characteristically Aristotelian view of politics. He wishes also to claim that a satisfactory account of political authority must focus on consent or other "positive" acts. But the claim that politics isn't natural doesn't explain that claim; rather, it repeats it. 
the others; each would doubt promises the others made; threats would be at best somewhat effective. We need not build any moral strictures into this game. The prudential argument proceeds easily without them.

That is why I have omitted Hobbes's putatively moral terms: right of nature, law of nature, transfer of right in covenant, and so on. They obscure the argument. Most often, the moral language can be transformed readily into the language of self-interest. So Hobbes explicitly transforms the laws of nature, here "but Conclusions, or Theoremes concerning what conduceth to the conservation and defence of themselves." ${ }^{37}$

The question, though, is whether all of Hobbes's putatively moral claims must be understood as disguised prudential claims. Here the spectre of psychological egoism rears its worrisome head to support an affirmative answer. It might seem that automatons mechanically pursuing self-interest simply cannot respond to the claims of morality, that a theorist describing such automatons cannot invoke those claims. Thomas Nagel, for example, has argued that there is no room in Hobbes for moral obligation, since "nothing could be called a moral obligation which in principle never conflicted with self-interest." ${ }_{38}$ Yet the view of Hobbes's psychological egoism I have offered allows us to exorcise this spectre. In my view Hobbes's egoism means only that we will unerringly submit to an absolute sovereign once we see that submission yields a state of affairs we deem good. But for the prudential argument, Hobbes needs to show only that peace is in everyone's interests, whether those interests are systematically pursued or not, whether they are egoistic or altruistic. He

${ }^{37}$ Leviatban, pp. 2 I6-2I 7 (EW III:147); note particularly Rudiments, p. I Io ( $E W$ II:2): "conditions of society, or of human peace, that is to say (changing the words only), what are the fundamental laws of nature." Hobbes also casts the law of nature as God's command. But I have nothing to contribute to the debate on the nature and sincerity of Hobbes's religious views. Hobbes discusses contemporary charges of atheism at $E W$ IV:292-295, 425-429; EW VII:349353.

${ }^{38}$ Thomas Nagel, "Hobbes's Concept of Obligation," Pbilosopbical Review 68 (January 1959): 74. See too Blair Campbell, "Prescription and Description in Political Thought: The Case for Hobbes," American Political Science Review 65 (June I 97. I): 380n. I 8: "A doctrine which suggests that we are always obliged to the state is not a moral doctrine." 
does not need to show that compliance with his proposals will in fact follow automatically. Egoism, then, however conceived, is simply not an essential part of the argument. In any case, we want to leave room both for ethical egoism, the view that each (morally) ought to pursue his or her own interests, and for arguments showing that, properly understood, morality and selfinterest coincide. Nagel's dictum would eliminate that room.

There may be room in Hobbes for morality, but it is quite another matter to show that the room is not empty. We can start by noting that the almost magical transformation of laws of nature into rational theorems cannot always be duplicated. Consider Hobbes's assertion that "it is not therefore the Victory, that giveth the right of Dominion over the Vanquished, but his own Covenant." ${ }^{39}$ A prudential reconstruction of "right of Dominion" would look something like: " $X$ has a right over $Y$ " means " $Y$ can recognize $X$ 's superior strength and obey his commands or suffer the consequences, and $Y$ is better off capitulating," along with riders about $X$. Why then is Covenant even relevant, let alone necessary? Why isn't sufficiently superior strength, or Victory, enough?

Consider too Hobbes's explanation of his claim that "contracts oblige us": "To be obliged, and to be tied being obliged, seem to some men to be one and the same thing; and that therefore here seems to be some distinction in words, but none indeed. More clearly therefore, I say this: that a man is obliged by his contracts, that is, that he ought to perform for his promise sake; but that the law tries him being obliged, that is to say, it compels him to make good his promise for fear of the punishment appointed by the law." ${ }^{40}$ Here Hobbes goes out of his way to distinguish a moral reason arising from promising itself from a prudential reason arising from the unpleasant prospect of punishment. I suppose it could be argued that the apparently moral obligation to keep promises is in the end as prudential as the other. After all, Hobbes argues that it is always in our interest to keep promises, since we can never sensibly risk the exclusion from society that

${ }^{30}$ Leviathan, pp. 255-256 (EW III: I 89).

${ }^{+0}$ Rudiments, p. 273n. (EW II: 185 n.). 
should follow the discovery that we have broken them. ${ }^{41}$ But I think this move fails to do justice to Hobbes ("he ought to perform for his promise sake," not his own sake). Perhaps my best reason for thinking so is Hobbes's independently grounded moral argument, which I discuss in the section on Science, Truth, and Morality.

I will argue, then, that the well-worn prudential argument is not an exhaustive account of Hobbes. Before pressing on, though, I want to make some critical remarks about that argument. I have discussed only sovereignty by institution, because I think Hobbes's use of sovereignty by acquisition gets him into trouble. He sometimes neatly joins the two: "If they fight, civil society ariseth from the victory; if they agree, from their agreement." ${ }^{2}$ If the hypothetical state-of-nature account is addressed to real people, this will not do. Suppose someone-call him Cromwell - proudly fancies himself strong; he may then be perfectly willing to risk the state of war, counting on his own quick victory and subsequent emergence as sovereign. After all, we "naturally love Liberty, and Dominion over others," on Hobbes's account. ${ }^{43}$ The argument can appeal to everyone's interests only if the state of war is bleak for everyone; Hobbes would do better to stick to his emphasis on equality and sovereignty by institution.

There are further tangles in the argument, tangles we can begin unraveling by focusing on peace. Hobbes's argument for the primacy of peace is an ingenious attempt to derive one good from the multiplicity of human goods, but it does not cut as deeply as he seems to think it does. He insists, for example, that "it is not possible there can be a greater" benefit than "the peace and preservation of every particular man." ${ }^{4+}$ Some of us, though, relish climbing sheer cliffs, fully aware of the risks; others relish war itself. Granted, these activities require some elements of cooperation and stability. Still, they can be pursued without the exten-

${ }^{41}$ Leviatban, pp. 203-205 (EW III: I 32-I 34), where Hobbes responds to the Foole.

${ }^{42}$ Rudiments, p. I I 3n. (EW II:6n.).

${ }^{43}$ Leviatban, p. 223 (EW III: 53 ), also p. 598 (EW III:572); $E W$ VI:404.

${ }^{44}$ Elements, p. 137 (EW IV:I6I). 
sive social peace Hobbes defends. Peace may well be a good most of the time for most of us, but that fact is glaringly insufficient for the prudential argument.

Doubtless Hobbes wishes to push past a description of the peaceful man on to an encomium to him. He wishes to condemn competitive souls, nobles seeking glory, religious fanatics, and power-hungry clerics, not just because they do not see the consequences of their actions, but also because they have bad desires, the wrong ends; they ought to have ends that don't threaten peace. Hobbes therefore tries to undercut much religion, to expose it gleefully as a mass of delusions, to discard it summarily as madness. He tries further to minimize the occasions for disobedience prompted by religious scruples. He wishes too, as in Bebemoth, to portray as vividly as he can the ravages of civil war. But we may suspect that these efforts will not certify peace as so extraordinarily important. Hobbes, of course, cannot think that all ends require peace. His saying so ignores the very nobles and religious fanatics whose eminently rational activities rip apart England and motivate his work. The apparent observation is then actually an idealization or a covert recommendation. Peace may not be a requisite for all ends, but think how much better off most of us would be if it were!

Note Hobbes's fifth law of nature:

That every man strive to accommodate bimselfe to the rest. For the understanding whereof, we may consider, that there is in mens aptnesse to Society; a diversity of Nature, rising from their diversity of Affections; not unlike to that we see in stones brought together for building of an $Æ d i f i c e$. For as that stone which by the asperity, and irregularity of Figure, takes more room from others, then it selfe fills; and for the hardnesse, cannot be easily made plain, and thereby hindereth the building, is by the builders cast away as unprofitable, and troublesome: So also, a man that by asperity of Nature, will strive to retain those things which to himselfe are superfluous, and to others necessary; and for the stubbornness of his Passions, cannot be corrected, is to be left, or cast out of Society, as cumbersome thereunto. ${ }^{45}$

${ }^{45}$ Leviatban, p. 209 (EW III: $3^{8-1}$ 39). I owe the following point to Stephen Holmes, who persuaded me that the prudential argument isn't exactly prudential. 
This passage invites a blandly prudential reading. Seeking peace will mean accommodating yourself, and since you want peace you had better do so. But again we can see a covert recommendation: since nobles and religious fanatics are useless stones that get in the way, throw them out. Their actions may be perfectly rational, given their ends. They will hardly be moved by Hobbes's argument. But because they interfere with the rest of us, our seeking peace will mean warring against them.

Note too the ninth law of nature:

If Nature therefore have made men equall, that equalitie is to be acknowledged: or if Nature have made men unequall; yet because men that think themselves equall, will not enter into conditions of Peace, but upon Equall Termes, such equalitie must be admitted. And therefore for the ninth law of Nature, I put this, That every man acknowledge other for bis Equall by Nature. ${ }^{46}$

It was because all men are equal that only capitulation to an absolute sovereign could do the trick. But now the argument is inverted: because capitulation is the end, all men had better think of themselves as equal. This puzzling move should at least give pause to those prone to thinking of conceptions of the self and the like as the heart of political theory, the base on which political conclusions are erected. As of ten as not, I suspect, revisions in such realms by political theorists are politically motivated.

These laws of nature disrupt the official claim that the laws of nature are "but Conclusions, or Theoremes," simple hypothetical imperatives. They also disrupt the claim that "all men agree on this, that Peace is Good." Not all men do agree that peace is good. The argument is not a simple prisoners' dilemma, since not all the players are aiming at peace. The players who do seek peace will simply have to throttle the others. Hobbes never even hints that the "true" self-interest of the latter group will thus be served. They will be tossed out of society, like irregular stones, and we will profit from their loss.

We can still wonder, however, whether Hobbes's prescriptions are good ones. Most objectionable is the linchpin of the argument, the claim that an absolute state is the means to peace.

${ }^{4}$ Leviatban, P. 2 I I (EW III: I4I). 
Hobbes has both empirical and conceptual reasons for thinking the state must be absolute. He relies on slippery-slope arguments to show that any limited state soon collapses, and on the concept of sovereignty to show that all power must lie in the hands of an assignable set of people above the law. But to anyone outside a society as politically fragile as the England of Hobbes's Bebemoth, the slippery-slope arguments are unpersuasive, as history attests. We have seen limited states survive quite handily. Sovereignty, on the other hand, is a good example of a theoretical concept that obfuscates the world instead of illuminating it. Divided sovereignty is a contradiction in terms. Political authority, however, can be divided and still exist: witness any federalist structure or division of powers. Similarly, political power can be limited by the rule of law. ${ }^{47}$

Arguably, the introduction of any state, absolute or not, as the solution of Hobbes's war of all against all is insufficiently motivated. Unless Hobbes entertains dubious beliefs about authority's moderating the passions of those in power, he should be worrying too about the (organized) war of some against the rest. The state, I would argue, emerges as the solution to Hobbes's problem only because he laboriously cloaks the state in the dreamy robes of mystification. It is striking that Hobbes bitterly condemns metaphor and himself develops an elaborate bodypolitic metaphor. ${ }^{48}$ That body politic, a mechanical one with springs, strings, and wheels, ${ }^{+9}$ sardonically mocks contemporary organic conceptions of society. It also systematically misdescribes the state, even the absolute state, in a way that has a political payoff. If the Leviathan state is a colossally large actor, even a "Mortall God," we will certainly cringe before it. Hobbes's sovereign, like the Wizard of $\mathrm{Oz}$, is an awe-inspiring figure. But is is, after all, only Hobbes behind the curtain, pulling the levers and creating that figure. We can play Dorothy, and demand that Hobbes unpack the metaphor and develop a

${ }^{+7}$ See the penetrating discussion in H. L. A. Hart, The Concept of Law (Oxford: Clarendon, 1975), pp. 49-76.

${ }^{+8}$ Leviathan, pp. I16-117, 81 (EW III:37, ix).

${ }^{+9}$ Leviathan, p. 8I (EW III:ix).

${ }^{50}$ Leviathan, p. 277 (EW III: 158 ). 
more straightforward justification. If anarchism (for that is what the state of nature is) is to be dismissed, we want to hear cogent arguments.

In this respect, the ahistorical pretensions of Hobbes's argument are a disability, not a strength. It may be that only an absolute state could have put an end to English civil war. But it is impossible to make any claims about what the life of masterless men necessarily is, for the character of that life will vary with social context. Asked to choose between anarchism and political society, with no context provided, we can only shrug. Is anarchism Hobbes's state of nature or a pastoral paradise? Is political society our favorite constitutional system or some totalitarian horror? For the choice to be intelligible, we need to constrain the set of possible outcomes; and the relevant constraints are at hand, in social context. Some possibilities-perhaps some of those a political theorist might dream up-are unavailable in the world.

The prudential argument has, as it must, a social context. Hobbes's desire to legislate timelessly, to frame a doctrine suitable for teaching ever after in the universities, ${ }^{51}$ prevents him from incorporating such contingent details of context. The argument takes on force and color, however, only when we make that context explicit, when we insert Bebemoth's perpetually obscure schoolmen and religious sects, its fractious nobles and insolent Parliament, into the political theory. Only then does the choice between anarchism and the state become definite enough to be meaningful.

"But then the argument is no longer timeless." That will depend on what we mean by timelessness. Surely we cannot simply slap Hobbes down on twentieth-century society as a justification for unquestioning obedience. We face not fragile governments on the verge of collapse, but overweening governments that themselves threaten peace. If they are gods, they are most assuredly Manichaean. If a timeless political theory

'Note Leviathan, pp. 384-385, 407-408, 727-728 (EW III:331-332, 357-358, 712-713); Thomas Hobbes, "The Life of Thomas Hobbes of Malmesbury," trans. J. E. Parsons, Jr., and Whitney Blair, Interpretation Io (January 1982): 5 . 
is one that applies regardless of social context, timeless political theories will be thoroughly vacuous.

\section{The Argument from Necessity}

"God is King of all the Earth by his Power," Hobbes announces. ${ }^{52}$ The claim seems innocent enough, but Hobbes spells it out in a sinister way. He appeals to necessity, and the argument from necessity covers more than God. The logic of the argument is bewildering and unsatisfactory. Here I start with Hobbes's views on God and then broaden my focus.

Hobbes wants to say not only that God does rule because of his infinite power, but also that "God in his natural kingdom hath a right to rule, and to punish those who break his laws, from his sole irresistible power." ${ }^{3}$ Underlining the point, he goes on to declare that "the obligation of yielding him obedience lies on men by reason of their weakness." ${ }_{54}$ Moreover, God's actions are self-justifying: "The power of God alone without other helps is sufficient justification of any action he doth."

We can immediately note a peripheral problem with this argument, one that parallels Hobbes's claims for the laws of nature. Hobbes wants to say that we are obliged to obey the laws of nature, understood as God's commands; he also wants to say that there is "no Obligation on any man, which ariseth not from some Act of his own"; so he is led to the obtuse claim that "the law of nature is the assent itself that all men give to the means of their own preservation," even though he also wants to say that "it is manifest that the divine laws sprang not from the consent of men,

${ }^{52}$ Leviathan, p. 179 (EW III:I05). And "we are Gods Slaves," Leviathan, p. 668 (EW III:648).

${ }^{3}$ Rudiments, p. 292 (EW II:206). I've changed Hobbes's italics.

${ }^{54}$ Rudiments, p. 294 (EW II:209).

${ }^{5 s} E W$ IV:249, discussed at $E W$ V: I I 5- I I7. Note that it isn't any special fact about God other than his power that gives rise to his right to rule; it isn't, for example, that God is essentially good and so gains the right to use his infinite power. Any irresistibly powerful agent has the right to rule: Rudiments, pp. 292-293 (EW II:206-207); Leviatban, p. 397 (EW III:345-346); $E W$ V:1 46; $E W$ IV:2 50, discussed at $E W$ V: 1 I 7- 147 . 
nor yet the laws of nature. For if they had their original from the consent of men, they might also by the same consent be abrogated; but they are unchangeable." ${ }^{6}$ As for God's right of ruling, Hobbes wants to say that it arises from God's irresistible power alone; but he says too "that the Right of all Soveraigns, is derived originally from the consent of every one of those that are to bee governed." ${ }^{7}$ The contradictions are comprehensible if, as I believe, Hobbes employs independent prescriptive arguments with different requirements. For the prudential argument, consent is unnecessary, and in fact entirely beside the point; but for the argument from ordinary language, consent may well seem crucial. The methodological moral of the story is simple: we can take outright contradictions in texts as signs that the author is juggling competing demands; then we can ask what those demands might be.

There is something odd in Hobbes's claims for God's deriving right from power. They smack of might makes right - and indeed Hobbes decrees also that "irresistible might in the state of nature is right." ${ }^{58}$ Some of the oddness fades away if we take these claims to be disguised prudential claims, and some of it fades away if we adopt a certain construction of justification.

Suppose we take " $X$ has a right to rule $Y$ " as meaning something like " $X$ is powerful enough to enforce her will on $Y, X$ is (possibly) inclined to do so, and $Y$ will deem himself better off by submitting," along with riders about $Y$ 's (possible) awareness of this state of affairs and ability to act purposively. Suppose further we take " $Y$ is obliged to obey $X$ " as meaning the same. ${ }^{59}$ These would be translations, if gimmicky ones, of the apparently moral claims we started with; but we would have moved wholly into the worlds of power and self-interest. If God's right is rendered in this way, the mystery and horror of, say, Hobbes's pronouncement that "irresistible might in the state of

${ }^{56}$ Leviatban, p. 3 I 2 (EW III:25 I); Rudiments, p. 207 (EW II: I Io); Leviatban, p. 268 (EW III:203); EW V:I 80; Rudiments, p. 273 (EW II: I 84).

${ }^{57}$ Leviatban, p. 599 (EW III:573).

${ }^{58}$ Elements, p. 74 (EW IV:86).

${ }^{59}$ See John Plamenatz, “Mr. Warrender's Hobbes," Political Studies 5 (October 1957): 296-297, reprinted in Brown, Hobbes Studies, p. 75. 
nature is right" dissolve. The point is simply that it is in everyone's interest to submit to one strong enough to be ruler when there is no ruler around already.

Brian Barry has made an apt suggestion for disposing of the troublesome claim that God is justified in whatever he does. ${ }^{60}$ We take justify to mean "make just": "I said no more," writes Hobbes, in explaining the dictum that "power irresistible justifies," "but that the power, which is absolutely irresistible, makes him that hath it above all law, so that nothing he doth can be unjust." 61 We then connect up this account of justification with Hobbes's account of justice, which is keeping contracts and obeying laws. ${ }^{62}$ Since the sovereign has made no contract with the rest of us and is above the laws, he cannot act unjustly: this is a matter of conceptual coherence, not a claim about the infallible wisdom or goodness of sovereigns. ${ }^{63}$ God is justified in all he does; that is, God acts justly in all he does; that is, God never breaks a law or violates a convenant - for to whose law is God subject? With whom has he covenanted ${ }^{64}$ Here too lies a possible explanation for Hobbes's qualification that only "power irresistible justifies all actions, really and properly, in whomsoever it be found; less power does not." 65 Very strong, even overwhelmingly strong, agents are actual or possible subjects of stronger agents, so we can conceive of their acting unjustly, that is, unjustifiedly. Only irresistibly strong agents are necessarily above the law.

${ }^{60}$ Brian Barry, "Warrender and His Critics," Pbilosopby 43 (April 1968): I 33n.9, uses the quotation I'm about to cite, but the quotation is at $E W V: 146$, not, as the article has it, $E W I V: 146$.

${ }^{6} E W$ V:I 46; also Elements, p. I 57 (EW IV:I86); Rudiments, pp. 382-383 (EW II:3 I 4); Leviathan, p. 623 (EW III:599-600).

${ }^{62}$ Leviathan, pp. 103, 202 (EW III:2 I, 131 I).

${ }^{63}$ Leviathan, pp. 232, 367 (EW III:163, 3 I 2-3 I 3); though see too $E W$ IV:333 ("an unjust judgment does not take away from any king his right of judicature"); Rudiments, p. I8 In. (EW II:8on.); and perhaps Leviatban, p. 325 (EW III:266), the only places I've found where Hobbes speaks of a ruler acting unjustly.

${ }^{64}$ In Hobbes's rendition of Abraham's covenant with God in Leviatban, pp. 499-50I ( $E W$ III:46I-463), God seems to commit himself to nothing; also $E W$ V:I I 7. But see Leviatban, pp. 443-444 (EW III:397-398), and Rudiments, pp. 3I I-3 I 2 (EW II:228-229), where God does guarantee Abraham the inheritance of Canaan.

${ }^{65} E W$ IV:250, discussed at $E W$ V: 1 $16-117$. 
Yet Hobbes appeals to necessity to make statements that do not lend themselves so readily to these kinds of explanation. Take his passing reference to "the natural right of preservation, which we all receive from the uncontrollable dictates of necessity." ${ }^{66}$ What might this mean? How do the dictates of necessity give rise to a right? Perhaps, as Hobbes sometimes maintains, we have to seek our own self-preservation. Perhaps we are built that way, out of genetic concrete. Mightn't that be wrong instead of right? Mightn't that be just another fact about human beings, and have no moral significance whatever? We might focus here on Hobbes's so-called naturalistic account of right and so take him to say only that we can try to preserve ourselves because we must. ${ }^{67}$ But Hobbes often does use right in a putatively moral way; he has in mind here not just physical obstacles to motion, but also moral constraints. ${ }^{68}$

I will take the liberty of quoting extensively, not to spread my confusion, but to suggest that it is not only my own. Hobbes has just explained why it is desirable to end the war of all against all, or, as he colorfully puts it, "to get some fellows":

Fellows are gotten either by constraint, or by consent; by constraint, when after fight the conqueror makes the conquered serve him, either through fear of death, or by laying fetters on him; by consent, when men enter into society to help each other, both parties consenting without any constraint. But the conqueror may by right compel the conquered, or the strongest the weaker (as a man in health may one that is sick, or he that is of riper years a child), unless he will choose to die, to give caution of his future obedience. For since the right of protecting ourselves according to our own wills, proceeded from our danger, and our danger from our equality, it is more consonant to reason, and more certain for our conservation, using the present advantage to secure ourselves by taking caution, than when they shall be full grown and strong, and

${ }^{66}$ Rudiments, p. 90 (EW II:ii).

${ }^{67}$ See, for example, Leviatban, p. 189 (EW III: I I6); Rudiments, p. I I 5 (EW II:9); and note the odd formulation on children, Rudiments, p. 212 (EW II:115-116).

${ }^{68}$ See J. Roland Pennock, “Hobbes's Confusing 'Clarity'-The Case of Liberty," American Political Science Review 54 (June 1960): 428-436, reprinted in Brown, Hobbes Studies, pp. Io - I 16; and A. G. Wernham, "Liberty and Obligation in Hobbes," in Brown, Hobbes Studies, pp. I 1 7- 139. 
got out of our power, to endeavour to recover that power again by doubtful fight. And on the other side, nothing can be thought more absurd, than by discharging whom you already have weak in your power, to make him at once both an enemy and a strong one. From whence we may understand likewise as a corollary in the natural state of men, that a sure and irresistible power confers the right of dominion and ruling over those who cannot resist; insomuch, as the right of all things that can be done, adheres essentially and immediately unto this omnipotence hence arising. ${ }^{69}$

The passage begins harmlessly enough, at least for present purposes. The war of all against all ends by treaty or victory. (Again, Hobbes would do better to stick to sovereignty by institution instead of acquisition, to consent instead of constraint: the latter makes rebellion a tempting option for those counting on a victory in the state of nature.) Next we learn that not only can the conqueror compel obedience, he may do it, by right. At this point, all this business of the rights of the mighty is so much assertion, with nary a shred of support.

Hobbes's explanation follows. There is an activity named "protecting ourselves according to our own wills" - that is, doing what we think appropriate for safeguarding ourselves. We have a right to engage in this activity. Now, to skip a bit, it is reasonable to ensure our safety by dominating others when they are weak, rather than waiting to deal with them when they are strong and menacing; reasonable here, I take it, means "conducive to our ends," here to self-preservation. But the skipped bit is troublesome. Our right of self-preservation proceeds from our danger, which in turn proceeds from our equality. The move from equality to danger is an abbreviation of the argument that the lack of authority produces the war of all against all. But how does the right proceed from the danger? Perhaps Hobbes has in mind the relation between right and reason he sometimes recurs to: "All do grant, that is done by right, which is not done against reason." And perhaps we are to slip from "doing something by

\footnotetext{
${ }^{69}$ Rudiments, pp. I $18-1$ I9 (EW II: I $2-1$ 3); compare with Elements, p. 73 (EW IV:85).

${ }^{70}$ Rudiments, p. 122 (EW II:I 5); also Elements, p. 7 I (EW IV:83).
} 
right" to "having a right to do something"; that our ends are served by aggressing against the weak would then generate our right to do it. Perhaps; perhaps not. Given the opacity of the passage, any explication must be tentative.

The connection between right and reason needs to be worked out more carefully. Hobbes needs to explain just how the right arises. Instead he goes on to repeat himself: it is reasonable to dominate the weak, so it is unreasonable, or absurd, not to dominate them. Still we want an explanation, but Hobbes instead triumphantly unveils a troublesome general principle. How the principle is a corollary of the narrower claim Hobbes starts with is a puzzle, and why the stark fact of power should be thought to confer a right is a veritable labyrinth. Most perplexing, though, is the essential and immediate adherence of the right to the power. How do rights flow from power relationships? How do moral relations adhere to descriptive ones? Hobbes undoubtedly intends this claim to be the climax of the paragraph and the argument, but it is a profound muddle. Why the necessities of power or nature or anything else should be thought to give rise to moral relations is mysterious. Accordingly, here I dismiss the argument from necessity. It lapses into incoherence just when it needs to be clearest.

I have been probing the argument from necessity not because Hobbes uses it to defend bizarre moral principles, but because the logic of the argument is entirely opaque. Part of the opacity arises not from Hobbes's view of God, or his determinism, or any other aspect of the argument's content. It arises rather from the argument's form, and darkens more appealing principles: Consent obliges. Legitimate governments are those to which we consent. Legitimate governments are those to which we would consent in some special position. The verbal event we call "promising" obliges. Labor creates entitlements. Need creates entitlements. The minority is bound to support the elected outcome or candidate. The majority is bound to support the elected outcome or candidate. In short, rights, duties, obligations, justice, legitimacy, and all the other ghostly inhabitants of the moral menagerie are sired in the real world.

In all these cases, we are presented with a move from descrip- 
tive to evaluative or prescriptive, from fact to value, is to ought. The move in each case may be defensible, but surely it needs defense of some kind. (On the fact of it, the only thing separating these principles from Hobbes's more sinister claims about necessity is that we happen to prefer them.) So it will not do simply to propose our favorite moral principles and count on the audience's agreement. Someone may disagree, proposing what strikes us as an eccentric or pernicious principle. If overt disagreement does not create the demand for justification, doubt will. For one may entertain not just the least bit of doubt about our moral and political principles without being extremely stupid, corrupt, or perverse.

\section{Science, Truth, and Morality}

Hobbes does more, fortunately, than announce that certain (perfidious) moral relations arise from necessity. He offers a systematic account of truth and science, a foundation on which he self-consciously builds a moral argument. This account enables Hobbes to speak of the truth about morals and politics in the face of his moral skepticism, and to this account I now turn.

Hobbes tells us that "Morall Philosophy is nothing else but the Science of what is Good, and Evill, in the conversation, and Society of mankind," that "what hath hitherto been written by moral philosophers, hath not made any progress in the knowledge of the truth." II I will not attempt a full-dress review of Hobbes's epistemology, but I do want to sketch his views of science and truth. It will prove essential here to exploit the possibility that Hobbes makes false claims about the nature and potential of his argument. We need not, however, say that Hobbes is striving to conceal a philosophic teaching from the vulgar. More workaday (if less reverential) explanations will do the job. We might for example hold that Hobbes was confused. In any case, I suspect that the lion's share of the literature on Hobbes's method goes

'Leviathan, p. 216 (EW III:146); Rudiments, p. 96 (EW II:v). See $E W$ $V I: 362-364$ on the science of politics. 
awry by concentrating too much on his own glosses on his procedure. ${ }^{72}$ Here I would recommend a claim attributed to John Mitchell during the Watergate controversy: watch what we do, not what we say. Mitchell's Rule, if I may elevate it to a hermeneutic principle, provides an incisive guide to the study of political texts as well as political actors.

Hobbes is skeptical about induction: "Though a man hath always seen the day and night to follow one another hitherto; yet can he not thence conclude they shall do so, or that they have done so eternally. Experience concludeth nothing universally." ${ }^{3}$ This skepticism does not lead Hobbes to a wholesale rejection of the belief that we can figure out how the world works and so control it. Like the good Baconian he is supposed to be, he holds that "the end of knowledge is power." But "the natural reason of man, busily flying up and down among the creatures, and bringing back a true report of their order, causes and effects" does not, from the sense-data of experience, produce science: "When one is dealing with the truth of fact, it is not properly called science, but simply knowledge." 75

Science is awfully bleak stuff: "The first grounds of all science are not only not beautiful, but poor, arid, and, in appearance, deformed." "Those first grounds are the careful recording of definitions: "All sciences begin with definitions, or otherwise they

${ }^{72}$ Critics often focus on the resolutive-compositive method. See, for example, Leo Strauss, The Political Pbilosopby of Hobbes, trans. Elsa M. Sinclair (Oxford: Clarendon, 1936). Strauss also maintains (p. 163) that "the antithesis between classical and modern political philosophy, more accurately between Platonic political philosophy and that of Hobbes, is that the former orientates itself by speech and the latter refuses to do so." I believe, for reasons I set out in this section, that this is wrong. I tend to disagree too with J. W. N. Watkins's excellent Hobbes's System of Ideas (London: Hutchinson University Library, I 965), pp. 37-38. J. Weinberger, "Hobbes's Doctrine of Method," American Political Science Review 69 (December 1975): 1 336- I 353, an Aristotelian rejoinder to Hobbes, is about "morally intelligible whatnesses" (pp. 1 346- 1 347) and the like. Finally, Thomas A. Spragens, Jr., The Politics of Motion: The World of Thomas Hobbes (Great Britain: University Press of Kentucky, 1973), is a careful exploration of continuities and discontinuities between Aristotle and Hobbes.

${ }^{73}$ Elements, p. 16 (EW IV:I 8).

${ }^{7+} \mathrm{EW}$ I:7.

${ }^{75} E W$ I:xiii; De Homine, p. 4I. Compare with Rudiments, p. 375 (EW II:305).

${ }^{76} \mathrm{EW} \mathrm{I}: 2$. 
must not be called sciences, but mere verbiage." While typically explication of common usage does the trick, sometimes philosophers may define their own terms: "Whatsoever the common use of words be, yet philosophers, who were to teach their knowledge to others, had always the liberty, and sometimes they both had and will have a necessity, of taking to themselves such names as they please for the signifying of their meaning."

We link all these definitions together in propositions. "A proposition," Hobbes says, "is a speech consisting of two names copulated, by which he that speaketh signifies he conceives the latter name to be the name of the same thing whereof the former is the name; or (which is all one) that the former name is comprehended by the latter." We join (Hobbes would say "add") these propositions into syllogisms, and we pile syllogism upon syllogism. In the end we are manipulating words and definitions, and we arrive at "that conditional Knowledge, or Knowledge of the consequence of words, which is commonly called SCIENCE." ${ }^{80}$ For Hobbes, then, a science of politics is a body of knowledge about the meanings and entailments of political concepts. It is not a mass of statistics hammered into lawlike statements. It is not even the study of political regimes. Hobbes is openly contemptuous of observation of the world: "Every man that hath spare money, can get furnaces, and buy coals. Every man that hath spare money, can be at the charge of making great moulds, and hiring workmen to grind their glasses; and so may have the best and greatest telescopes. They can get engines made, and apply them to the stars; recipients made, and try conclusions; but they are never the more philosophers for all this." ${ }^{11}$ And since Hobbes equates science and philosophy in his grand schematic of human knowledge, neither are they scientists. ${ }^{82}$ Hobbesian scientists, after all, "proceed from most low

\footnotetext{
${ }^{7}$ De Homine, p. 69; also EW VII:222, 225.

${ }^{78} \mathrm{EW}$ I: 16.

${ }^{79} \mathrm{EW} \mathrm{I}: 30$.

${ }^{80}$ Leviatban, p. I 3 I (EW III:53).

${ }^{81} E W$ IV:436.

${ }^{82}$ Leviatban, p. 149 (EW III:72).
} 
and humble principles, evident even to the meanest capacity, going on slowly, and with most scrupulous ratiocination (viz.) from the imposition of names they infer the truth of their first proposition; and from two of the first, a third; and from any two of the three a fourth; and so on. ${ }^{{ }^{83}} \mathrm{We}$ are a long way indeed from $\mathrm{Ba}$ con's program.

What does it mean to say a proposition is true? Hobbes sounds sometimes as though he wants to confine truth to the same analytic framework as science: "When two names are joyned together into a Consequence, or Affirmation; as thus, $A$ man is a living creature; or thus, if be be a man, be is a living creature, If the later name Living creature, signifie all that the former name man signifieth, then the affirmation, or consequence is true; otherwise false. For True and False are attributes of Speech, not of Things." "84 "Man is a living creature": what better example of a tautology could we ask for? If truth and falsehood "are attributes of Speech," how can we possibly understand claims about the external world as being true or false? Science is but a collection of tautologies; tautologies are the only examples of true propositions. Or so it might seem; but Hobbes, again, does talk about "the truth of fact," and he does try to stretch his theory of truth to handle synthetic propositions: "A true proposition is that, whose predicate contains, or comprehends its subject, or whose predicate is the name of every thing, of which the subject is the name; as man is a living creature is therefore a true proposition, because whatsoever is called man, the same is also called living creature; and some man is sick, is true, because sick is the name of some man." ${ }_{85}$ It is a bit artificial to say that "some man is sick, is true, because sick is the name of some man," but Hobbes needs to say it in order to hold to his claim that truth "consists in speech, not in the things spoken of." ${ }^{86}$ Still, he does maintain there is a difference between analytic and synthetic propositions: the former he calls "necessary," and offers as an example "man is a rational liv-

${ }^{83}$ Elements, p. 66 (EW IV:72-73).

${ }^{84}$ Leviathan, pp. I04-105 (EW III:23).

${ }^{85} E W$ I:35.

${ }^{86} E W$ I:35; also Elements, pp. $21-22$ (EW IV:23-24). 
ing creature"; the latter he calls "contingent," and offers as an example "every crow is black." ${ }^{87}$ Let me note at once that I will not bring in Quine and other critics of the analytic/synthetic dichotomy. While their criticisms would provide a potent line of attack from outside Hobbes's theory, I mean to show that the theory is internally flawed. Accordingly, I will proceed in blithe disregard of recent strictures on the dichotomy.

Hobbes maintains too that "every proposition, universally true, is either a definition, or part of a definition, or the evidence of it depends upon definitions. " Now, since Hobbes wants to model moral and political science (or philosophy) after geometry, "the onely Science that it hath pleased God hitherto to bestow on mankind," and since the conclusions of geometry are "indisputable," it might seem that Hobbes would be perfectly content to reserve the name science for wholly analytic systems, as I believe he is committed to doing by his account of the matter. ${ }^{89}$ But he also wants to incorporate empirically oriented causal models: "till we come to [I] a knowledge of all the Consequences of names appertaining to the subject in hand; and that is it, men call SCIENCE. And whereas Sense and Memory are but knowledge of Fact, which is a thing past, and irrevocable; Science is [2] the knowledge of Consequences, and dependence of one fact upon another; by which, out of that we can presently do, we know how to do something else when we will, or the like, another

${ }^{87} E W$ I:37-38, italics omitted. Hobbes draws the distinction around whether we can conceive of the proposition being false. Compare Dorothea Krook, "Thomas Hobbes's Doctrine of Meaning and Truth," Pbilosophy $3 \mathrm{I}$ (January 1956): 6: "For Hobbes, all truth is 'analytic." Hobbes says "that the method of attaining to the universal knowledge of things, is purely analytical" $(E W$ I:69); but there is nonuniversal knowledge, which is knowledge of fact.

${ }^{88} E W$ I:62. Sheldon Wolin, Hobbes and the Epic Tradition of Political Theory (Los Angeles: University of California Press, 1970), p. 22, goes too far in saying, "All is changed by the advent of method, for it magnifies human power and certitude. Reason is rendered infallible." Right reason is infallible, but we never know if we have right reason; see, for instance, Elements, pp. 188- i89 (EW IV:22 5); Rudiments, p. 303 (EW II:2 20); Leviathan, p. I I (EW III:30-3I); EW $\mathrm{V}: 176,194$. Method, however, surely is important; note Leviathan, p. I 14 (EW III:33); see too $E W$ VII:84.

${ }^{89}$ Leviathan, pp. 105, I14 (EW III 23-24, 33); also Rudiments, pp. 91-92, 373-374 (EW II:iv-v, 302-303); EW I:38; Elements, p. 176 (EW IV:2 10). 
time." ${ }^{90}$ Consequences of names and consequences of facts, nestled together: Hobbes seems to believe the two are the same, or that somehow attaching causal models to facts makes a body of knowledge of consequences of names. ${ }^{91}$

But how might causation enter this arid world of syllogisms? Hobbes makes three suggestions. First, he exploits his skeptical tendencies. "The doctrine of natural causes hath not infallible and evident principles," ${ }_{92}$ so we must suppose possible causal links between events and, in turn, if a bit mysteriously, between words. Here Hobbes is willing to consider empirical evidence, for even a possible causal connection must not, he thinks, fly in the face of the evidence. ${ }^{93}$ Second, in morals and politics, "we ourselves make the principles," 94 so we can know their causal underpinnings with certainty. Third, Hobbes proposes that we define things by their method of generation, or cause. ${ }^{95}$ Yet wherever our causes come from, Hobbes relies on syllogistic inference to preserve the causal connections. Here he confounds logical and empirical necessity, but the two are different. It may be causally necessary that water freeze at zero degrees and normal pressure. We can though conceive of its not doing so, so it is not logically necessary. ${ }^{96}$

Ambitious claims for what Hobbes's science can accomplish must then be discarded. Causal models are not guaranteed correct by the meanings of the terms they are composed of. Nor do any of Hobbes's efforts at patching over the problem succeed. We must, then, turn our attention away from his repeated

${ }^{90}$ Leviatban, p. I I 5 (EW III:35).

${ }^{9}$ See McNeilly, Anatomy of Leviatban, pp. 59-91; also William Lyons, "Against an Orthodox Interpretation of Hobbes," Pbilosopbical Quarterly 27

(October 1977): 302-31 2 .

${ }^{92} E W$ VII:3.

${ }^{93}$ See $E W$ VII: I- I 77, particularly 3-4, 88.

${ }^{4}$ De Homine, p. 42; also $E W$ VII: $183-184$. Compare the introduction to Leviatban.

${ }^{95} E W$ I:81-83; compare $E W$ I:3 I I-3 I 2, EW VII:2 I 2, and see generally $E W$ I:387-388.

${ }^{9}$ Note Richard Peters, Hobbes (Harmondsworth: Penguin, 1956), pp. 52-54. Hume, among many others, reproduces the confusion: note J. L. Mackie, The Cement of the Universe (Oxford: Clarendon, 1980), pp. 3-28. 
glosses of science and philosophy as including causal models, his willingness to call astronomy a science right along with geometry, and his well-known remarks on the resolutive-compositive method. ${ }^{97}$ They are flashy, they are provocative, and they are memorable. Unhappily, they are also misleading.

To be sure, Hobbes employs the resolutive-compositive method in constructing the hypothetical state of nature, and he employs causal reasoning to argue, say, that we ought not to limit the sovereign's powers. I do not mean to brush aside these arguments. Rather I want to show that Hobbes grounds a moral argument on the analytic account of science, that he is aware he is doing so, and that this account enables him to claim to have provided the truth about morals and politics, the new political science. I want to show too that Hobbes is sometimes aware that his political science is doomed to triviality.

Consider: "And when a man hath in either manner abandoned, or granted away his Right; then is he said to be OBLIGED, or Bound, not to hinder those, to whom such Right is granted, or abandoned, from the benefit of it: and that he Ought, and it is his Duty, not to make voyd that voluntary act of his own: and that such hindrance is INJUSTICE, and INJURY."98 Here Hobbes offers a thumbnail sketch of the terrain of our moral concepts. Notice that he is reporting the ways in which we hook up these concepts: it is said one is obliged on surrendering a right, it is said one ought to let others enjoy rights surrendered to them, it is said it is one's duty, and so on. I take this passage to be an explication of the ordinary usage of the major moral concepts.

Now Hobbes's science comes into play, and these reports of common usage are transformed into true propositions. Hobbes need not limit himself to reporting common usage: he can say that "it is unjust to trespass on others' rights" or that "it is one's duty not to hinder those to whom one has transferred a right in their enjoyment of it." These are true propositions, guaranteed correct by the meanings of the words they are composed of; so

${ }^{97}$ See, for example, De Homine, pp. 41-43; EW I:82-83; Leviatban, p. 682 ( $E W$ III:664); $E W$ I:10, 66; and note the benefits of philosophy at $E W$ IV:449-450.

${ }^{94}$ Leviatban, p. I9I (EW III: I 19). 
they are the building blocks of Hobbes's moral science. It does not matter that Hobbes believes that good and bad are subjective, that he presumably believes that obligation and the rest are epistemologically suspect. We do use the words in an internally coherent framework, and that is all Hobbes the scientist needs in order to go about his work.

Hobbes clearly understands himself as carrying on this sort of scientific inquiry into morals and politics. In the chapter "Of Civil Lawes" in Leviatban, he commences by making some observations about the logical features of the concept law. He then proceeds to formulate a definition clearly intended as explication of common usage ("in which definition, there is nothing that is not at first sight evident"), and remarks, "Whatsoever can from this definition by necessary consequence be deduced, ought to be acknowledged for truth. Now I deduce from it this that followeth." Crystal clear too is Hobbes's summation of the first two parts of Leviatban, a summation he offers at the start of the third part, before he enters into his fantastic disquisition on Scripture: "I HAVE derived the Rights of Soveraigne Power, and the duty of Subjects hitherto, from the Principles of Nature onely; such as Experience has found true, or Consent (concerning the use of words) has made so; that is to say, from the nature of Men, known to us by Experience, and from Definitions (of such words as are Essentiall to all Politicall reasoning) universally agreed on."100 The argument "from the nature of Men, known to us by Experience" I have been calling the prudential argument; the argument "from Definitions (of such words as are Essentiall to all Politicall reasoning) universally agreed on" I have been calling the argument from ordinary language. I have paid no attention to Hobbes's occasional claim, voiced here, that we consent to the meanings of words. Taking the claim seriously could mean lending moral force to his scientific argument. If consent obliges, and we have consented to the meanings of words, then perhaps we are morally bound to observe conceptual connections. But the sort of consent that we give to the

\footnotetext{
${ }^{99}$ Leviathan, pp. 3 I I - 3 I 2 (EW III:250-252).

${ }^{100}$ Leviatban, p. 409 (EW III:359). Compare Rudiments, p. 367 (EW II: 295-296).
} 
meanings of words is surely too tenuous to have any moral import. The introduction of consent only obscures the sense in which Hobbes wants to endorse our conventional views.

Hobbes does not believe that whatever conventional moral views we hold are true simply because we hold them. He believes, on the contrary, that our moral views are abominably confused, that "it would be an incomparable benefit to commonwealth, if every man held the opinions concerning law and policy" that he, Thomas Hobbes, holds. He scorns "vulgar received opinions, which for the most part are erroneous." 101 Nor does he want to enshrine "those hermaphrodite opinions of moral philosophers, partly right and comely, partly brutal and wild; the causes of all contentions and bloodsheds." ${ }^{102} \mathrm{He}$ wants to concentrate on the logical characteristics of the moral and political concepts; only on these can he construct a scientific system of necessary truths.

Hobbes, then, seems committed to the extravagant view that a purely formal analysis, with a paucity of constraints, will yield substantial conclusions. Only with that commitment will he be able to move past trivialities in his moral and political science. Yet Hobbes labors under no such delusions. He knows that purely formal analysis yields empty conclusions: "It is impossible to be determined by the consent of single men, whom the same things do not please and displease, what actions are, and what not to be blamed. They may agree indeed in some certain general things, as that theft, adultery, and the like are sins; as if they should say that all men account those things evil, to which they have given names which are usually taken in an evil sense. But we demand not whether theft be a sin, but what is to be termed theft; and so concerning others, in like manner." ${ }_{103}$ The quotation is not quite to the point, but the path leading from one to the other is quite short and is well traveled by Hobbes.

${ }^{10}$ Elements, p. xvi (EW IV:xiv); Rudiments, p. 23 I (EW II:I37). Elements, p. 65 (EW IV:7I): "Commonly truth is on the side of the few, rather than of the multitude," perhaps because of "the ordinary ignorance, stupidity, and superstition of mankind," Leviathan, pp. 474-475 (EW III:433). See too $E W$ VI:343.

${ }^{102}$ Rudiments, p. 98 ( $E W$ II:xiii). Note $E W$ VI:282-283 on "the babbling philosophy of Aristotle and other Greeks"; $E W$ VII:75-76; and, of course, the famed chap. 46 of Leviathan.

${ }^{103}$ Rudiments, p. 283 (EW II: 196-197). 
It is, in fact, one step. Hobbes holds a strikingly modern theory of evaluation and language: "Men, by giving names, do usually not only signify the things themselves, but also their own affections, as love, hatred, anger, and the like." ${ }^{104}$ His favorite example is tyranny: "They that are discontented under Monarchy, call it Tyranny"; but the form of government is still the same, even if "misliked." 105 He says too, for example, that pusillanimity is called "Wretchednesse, Miserablenesse, or Parsimony; as it is liked, or disliked." 106 Many concepts, as we might say, have descriptive and evaluative components. Now the moral concepts have evaluative and prescriptive force; if they are to appear in necessarily true propositions, they must be linked to other evaluative and prescriptive concepts. Substantial moral claims - those that assert, say, that we ought to engage in some descriptively understood activity - cannot be necessarily true, since we can conceive of their contrary as being true. We understand, whether we agree or not, the claim that we ought never to aid our neighbors. Here is why, methodologically speaking, Hobbes's moral science does not embrace common moral opinions: not only are they wrong, they have substance.

Theft is wrong, for we mean by theft "wrongful taking of another's property." But we need yet to know just what activities constitute theft. That question is beyond the horizons of Hobbes's moral science. Its findings are true only because they are purged of content; the argument from ordinary language fails, as it must. For "we demand not whether theft be a sin, but what is to be termed theft, and so concerning others, in like manner."

\section{A Substantial Moral Argument?}

Hobbes is caught. The prudential argument fails to provide a genuinely moral rationale for obeying the sovereign in all things,

${ }^{1}$ Rudiments, p. 192 (EW II:93); also Leviatban, p. I65 (EW III:90).

${ }^{105}$ Leviathan, pp. 239-240 (EW III:I 7 I-I 72$)$, and pp. 369-370, $722(E W$ III:3 I 5, 706); also Rudiments, pp. $192-193$ (EW II:93-94); EW V:2 15.

${ }^{106}$ Leviatban, p. 123 (EW III:44). More examples: Elements, pp. 37, 38, 43, I 09, I I 4- I I 5 (EW IV:40-4I, 42, 48, I 27- I 28, I 34). 
and Hobbes does want a genuinely moral argument. Yet the only argument he can muster to the cause, the argument from ordinary language, is empty: it fails to dictate anything at all. How, then, can he ground a moral argument dictating obedience to an absolute sovereign? Hobbes makes two attempts here. Neither works.

Perhaps uncharitably, I view the first as an attempt to rig the terms of the argument from ordinary language. Hobbes's political science, remember, is concerned with "such words as are Essentiall to all Politicall reasoning." Some of them- "justice," or "right," for example - are specialized moral concepts; but some - "sovereign," or "law", for example-are ostensibly descriptive. Hobbes departs from explication in defining the latter sort: "And in him [Leviathan] consisteth the Essence of the Commonwealth; which (to define it,) is One Person, of whose Acts a great Multitude, by mutuall Covenants one with another, bave made themselves every one the Autbor, to the end be may use the strength and means of them all, as he shall think expedient, for their Peace and Common Defence. And he that carryeth this Person, is called Soveraigne, and said to have Soveraigne Power." 107 A sovereign carries the person of the great multitude, each of whom is the author of his acts. Now consider what Hobbes has to say about the "author":

Of Persons Artificiall, some have their words and actions Owned by those whom they represent. And then the Person is the Actor; and he that owneth his words and actions, is the AUTHOR: In which case the Actor acteth by Authority. For that which in speaking of goods and possessions, is called an Owner . . speaking of Actions, is called Author. And as the Right of possession, is called Dominion; so the Right of doing any Action, is called AuTHORITY. So that by Authority, is alwayes understood a Right of doing any act; and done by Autbority, done by Commission, or Licence from him whose right it is. ${ }^{108}$

Actors have a right to do what they are authorized to do; the sovereign, then, by definition, has a right to do what he does. Hobbes makes much the same move in discussing law: "It is manifest,

${ }^{107}$ Leviatban, p. 228 (EW III: I $\left.5^{8}\right)$.

${ }^{108}$ Leviatban, p. 2 I 8 (EW III: I 48). 
that Law in generall, is not Counsell, but Command; nor a Command of any man to any man; but only of him, whose Command is addressed to one formerly obliged to obey him." ${ }_{109}$ We are, by definition, obliged to obey the law. That is what a law is. We are also obliged to obey the sovereign (I leave Hobbes to scientifically transform the transfer of right into obligation: "When a man hath . . . granted away his Right; then is he said to be Obliged"). That is what a sovereign is.

The flaw is obvious enough. If he likes, Hobbes can exercise his privileges as a philosopher and define his terms as he will. He can carefully build the appropriate evaluative and prescriptive components into his definitions of the moral and political concepts. He can then claim that laws and sovereigns ought to be obeyed, and can attach all the splendor of scientific veracity to his claim. But we can demand not whether laws oblige or sovereigns act by right, but what are to be termed laws, what sovereigns, and so concerning others, in like manner. If being a sovereign means, among other things, having the right to do what one does, those we commonly think of as sovereigns (because they wield power in a certain way) may not be sovereigns at all: they may act without right. There may be no sovereigns, no laws, in Hobbes's sense. An argument intended to show that we ought to obey the sovereign cannot commence with that view built into the definitions, else we may fairly decide that its author is trying to smuggle in his own prescriptive views under the guise of describing common usage. Even if common usage made that tie analytic, we could always employ an open-question argument and drive in a skeptical wedge. That is, even if we did commonly understand laws to oblige by definition, we could sensibly inquire whether this putative law really does oblige, whether it "really" is a law at all. Verbal maneuvers don't resolve substantive questions. ${ }^{110}$

The second attempt is more interesting. Hobbes is captivated

${ }^{109}$ Leviathan, p. 3 I 2 (EW III:25 I).

${ }^{110}$ Compare Anthony Quinton, "On Punishment," Analysis 14 (June I 954): I 33-142, and John Rawls, "Two Concepts of Rules," Philosophical Review 64 (January 1955): 3-32, both reprinted in The Philosophy of Punishment, ed. H. B. Acton (New York: St. Martin's Press, I 969). Similar objections may be pressed against the position Ronald Dworkin stakes out in his Taking Rights Seriously (Cambridge, Mass.: Harvard University Press, I980). 
by moral disagreement and makes striking claims for its importance: "All controversies are bred from hence, that the opinions of men differ concerning meum and tuum, just and unjust, profitable and unprofitable, good and evil, bonest and dishonest, and the like; which every man esteems according to his own judgment." signification," since we use them (in part) to express our own affections. ${ }^{112}$ Hobbes seems sometimes to believe that the damnable world of human conflict would evaporate if only we could agree on the use of words. "The authors of sedition," he tells us, "be such, as name things not according to their true and generally agreed-upon names; but call right and wrong, good and bad, according to their passions, or according to the authorities of such as they admire, as Aristotle, Cicero, Seneca, and others." 113

Insofar as language is at stake here, Hobbes is heading precisely backwards. For all the interesting ways in which language shapes our world, it's not that we have conflicting opinions, and so sometimes come to blows, because we use evaluative concepts differently. It's rather that we use evaluative concepts differently because we have conflicting opinions. Regardless, Hobbes is making a beeline for the argument from ordinary language, and we are once again in the world where definition is all-important and the meanings of words reign. This time, though, neither ordinary usage nor the fiat of philosophers or mathematicians is decisive. The verdict of the sovereign is.

To complete the quotation on the importance of moral disagreement: "It belongs to the same chief power to make some common rules for all men, and to declare them publicly, by which every man may know what may be called his, what another's, what just, what unjust, what good, what evil."114 Here Hobbes's sovereign appears as the ultimate linguistic arbiter, and

"'Rudiments, p. 178 (EW II:77).

${ }^{112}$ Leviatban, p. I09 (EW III:28), italics removed.

${ }^{113}$ Elements, p. 177 (EW IV:2.I I). So should we say that Hobbes's decidedly eccentric explication of the political concepts makes him an author of sedition?

${ }^{114}$ Rudiments, p. 178 (EW II:77). For one reading of the political implications of the sovereign's linguistic authority, see Sheldon Wolin, Politics and Vision (Boston: Little, Brown, I 960), pp. 239-285, especially 257-262. 
here Hobbes offers strikingly legalistic accounts of the moral and political concepts: "For not every taking away of the thing which another possesseth, but only another man's goods, is theft; but what is our's, and what another's, is a question belonging to the civil law."115

So far Hobbes is still firmly in the realm of the prudential argument. Once we recognize the disastrous effects of moral disagreement and the inconstancy of moral concepts, we should readily flock to the sovereign and slavishly adopt his proffered definitions of the relevant words. Our agreement is more important than what it is we agree on. But this time Hobbes cannot even rely on what little plausibility the prudential argument has. Our moral disagreement is not so important. Nor would the Orwellian maneuver of enforcing a set of definitions remedy conflict. There are real conflicts of interest in the world, far removed from dictionaries. Words can be weapons-we must assent to Hobbes's grim claim that "the tongue of man is a trumpet of war and sedition" 116 _ but people wield them for reasons. Without venturing any suggestions on better theoretical frameworks for understanding strife, I do want to suggest, if only editorially, that Hobbes's view of the matter is exotic. Yet he needs that view to head toward the argument from ordinary language.

Hobbes's thoughts on the sovereign and language may seem to lead him to a marriage of the prudential argument and the argument from ordinary language. He insists vehemently on the linguistic powers of the sovereign. He even refers to "him that hath the Power to prescribe the Rules of Right and Wrong; that is, to make Laws" and says that "the civil laws [are] the rules of good and evil, just and unjust, bonest and dishonest; that therefore what the legislator commands, must be held for good, and what he forbids for evil." 117 In a section entitled "It pertains to the civil authority, to judge (when need requires) what definitions and what inferences are true," Hobbes says that "the decision of the ques-

${ }^{115}$ Rudiments, p. 185 (EW II:85); also Leviathan, p. 328 (EW III:269).

${ }^{116}$ Rudiments, pp. $168-169$ (EW II:67).

${ }^{117}$ Leviathan, p. 594 (EW III:568) and p. 697 (EW III:680-68I); Rudiments, p. 244 (EW II: I 50) and the following pages. 
tion, whether a man do reason rightly, belongs to the city." 118 Perhaps Hobbes believes that the sovereign's decreeing something to be the case makes it the case, that truth is a matter of political decree. Certainly Hobbes exalts the state, his "Mortall God." Who knows how godlike he thought it? Or, less extravagantly, perhaps Hobbes believes that true means "vouched for by the state." Either move would place him in a position to reformulate the argument from ordinary language. He could dress it up as the argument from political decree; with his new account of truth, he could say that civil laws are moral truths. Then he would have a genuinely substantial moral argument (a significantly relativist one, though, since even the least fickle sovereigns change laws, and different sovereigns enact different laws, each of which would be, on this account, true in its time and place).

Such an argument, though, would make mincemeat of our notion of truth. I am inclined to think that Hobbes makes no such argument, and that his apparently contrary statements on the Olympian linguistic powers of the sovereign are just catchy slogans, formulations imposed by his contentiousness. ${ }^{119}$ What remains after the sensationalist dust settles is the more straightforward claim: it is in our self-interest to accept the sovereign's verdict on truth and falsehood, just as it is to accept his verdict on what constitutes theft and adultery. We can then place my reading squarely between those of Watkins and Warrender. Watkins claims that Hobbes's sovereign "must be a single determinate body who will fill the natural moral vacuum by issuing laws which will create moral distinctions and regulate relations between men"; Warrender claims that "the sovereign provides conditions which render operative obligations, which previously are but imperfectly effective." ${ }^{120}$ Watkins's view, that the sover-

${ }^{118}$ Rudiments, pp. 329,344 (EW II:268, 269). At $E W$ VI: 175 , Parliament defines beresy.

${ }^{119}$ Though we do have Hobbes's demurrer, "I only do reason, I dispute not," Rudiments, p. 103 (EW II:xx). I wonder what Wallis or Bramhall would say. Note $E W$ VII:332-337. For some of Hobbes's marvelous boasting, see $E W$ I:ix; $E W$ IV:436-437; $E W$ VII:242, 47 I.

${ }^{120} \mathrm{~J}$. W. N. Watkins, "Philosophy and Politics in Hobbes," Pbilosophical Quarterly 5 (April 1955): 145 and 141, revised and reprinted in Brown, Hobbes 
eign creates moral distinctions, is too strong; Warrender's, that the sovereign supplies validating grounds of obligation, is too weak. The moral distinctions are built into the language, but they are empty; it is up to the sovereign to lend them content.

In the end, then, Hobbes can support his contention that we ought to submit to an absolute sovereign only by appealing to prudential considerations. His moral argument remains empty: he can show that we ought to fulfill our obligations, but he cannot show that there is any particular activity we are obliged to engage in. Squeezing obligations into the definitions of sovereign and law gets Hobbes nowhere; and the marriage of the prudential argument and the argument from ordinary language, even if Hobbes is foolhardy enough to attempt it, is barren.

So I return to a familiar idea: Hobbes offers no satisfactory account of the moral relations between individuals and the state. Nor does his prudential argument succeed. Hobbes's political theory purchases its crystalline precision by forfeiting engagement with concrete issues. As a result, Hobbes fails to justify his conclusions. But perhaps a political theorist willing to go beyond abstract renditions of self-interest and political language will not fail to justify his conclusions. Accordingly, I turn now to John Locke.

Studies, pp. 262 and 258; and Watkins, Hobbes's System of Ideas, pp. I 38 , 144-145, I64; Warrender, Political Pbilosophy of Hobbes, p. 144 and pp. I 14- I I8, though see p. I63. 